\title{
Justi's Essay on Universal Monarchy (1747): A Misunderstood Satire*
}

\author{
ERE NOKKALA
}

\section{Introduction}

Johann Heinrich Gottlob von Justi's $(1717-1771)^{1}$ work has proved difficult to contextualise and interpret. There is consensus that he was one of the most influential German political and economic writers from the 1750s to 1770s; however, evaluations of the value and originality of his work vary greatly. Traditionally, Justi has been seen as one of the leading German cameralists ${ }^{2}$ that is to say, as a specialist of the mercantilist policy of the state. Reinterpretations of cameralism and cameral sciences have changed and keep changing the ways the main proponent of cameral sciences has been seen during the past forty years. ${ }^{3}$ We have come to realise that cameralists wrote extensively on political

This article draws on chapter 6 of my monograph: Ere Nоккаца, From Natural Law to Political Economy: Johann Heinrich Gottlob von Justi on State, Commerce and International Order, Berlin 2019, pp. 170-204. This article provides more textual evidence to support my interpretation and explains in greater depth the meaning of Justi's essay on universal monarchy in its political context.

1 Justi had a very eventful and colourful life. He started his career as a soldier in the Saxon army before studying legal and cameral sciences in Wittenberg from 1742 to 1744 . In 1745 he began publishing his first journal and from that time onwards he was always managing at least one journal. In 1747 Justi won an essay prize contest set by the Royal Prussian Academy of Sciences with his text Nicbtigkeit und Ungrund der Monaden, in which he criticized Leibniz's and Christian Wolff's theory of monads. In this same year Justi had been appointed to the service of the widowed Duchess of Sachsen-Eisenach. Three years later, in 1750, Justi went to Vienna, where he was called upon to be chair of eloquentia Germanica at the Theresianum, Maria Theresa's new ,imperial academy" for recruits to the civil service. From 1752 he became its professor of Praxis im Cameral-Commercialund Bergwesen. In the following year Justi moved to Leipzig and from there in 1755 to Göttingen, where he became Ober-Policey-Commissar and the first lecturer to teach cameral sciences at the University of Göttingen. Soon after, in 1757, Justi left Göttingen and went to work for the Danish Court. After a short period in Denmark he supported himself until 1765 as an independent writer. This was the time when he wrote most actively. He was granted a pension from Prussia for his pro-Prussian and pro-English pamphlets. In 1765 he was appointed as an inspector of mines, glassand steelworks (Berghauptmann) in Prussia. Three years later he was accused of having misused the state's money. Justi died in 1771, nearly blind and accused of embezzlement, imprisoned in Küstrin.

2 Ferdinand FrensdorffF, Über das Leben und die Schriften des Nationalökonomen J. H. G. von Justi, Göttingen 1903; Justus Remer, Johann Heinrich Gottlob Justi: Ein deutscher Volkswirt des 18. Jahrbunderts, Stuttgart 1938.

3 For new interpretations of cameral sciences, cameralists and cameralism see Marten SePPEL, Introduction: Cameralism in Practice, in: Marten Seppel - Keith Tribe (edd.), Cameralism in Practice: State Administration and Economy in Early Modern Europe, Woodbridge 2017, pp. 1-16; Ere 
and economic matters beyond merely defending the mercantilist policy of a princely state. In the 1980s, Horst Dreitzel and Hans Erich Bödeker situated Justi within the framework of the politicisation of the Enlightenment in Germany. ${ }^{4}$ Radically extending beyond this, Marcus Obert and Uwe Wilhelm interpreted Justi as an early liberal. ${ }^{5}$ The most recent historiographical turn has been to place Justi's work in the framework of European eighteenth-century discussions on political economy. ${ }^{6}$

Whereas many new aspects of Justi's economic and political thought have been found, plenty more remain to be discovered. Among the aspects that deserve closer scrutiny are Justi's writings on the law of nations and his career as a satirist. This essay is a contribution to both of these understudied and often misunderstood parts of Justi's work. Namely, in this article, I argue that Justi's early essay on universal monarchy was an extension of his career as a satirist. This is to say that one of his first works on European order was in fact a satire.

Justi was one of a handful of German satirists. ${ }^{7}$ The first book Justi ever published was a satire titled Dichterinsul (1745). ${ }^{8}$ It was an allegorical journey from the city of Decayed Language (Sprachverderb) to the land of Poetry (Dichtkunst) and its capital, Reason (Vernunft), where the land was cultivated and its ruler, the great Gottfried, had invented the flute. Justi's satire was a success. It sold out and was positively reviewed in Göttingische Zeitungen von Gelehrten Sachen. ${ }^{9}$ The eminent writer Johann Gottsched (1700-1766) praised Justi's writing for its originality, praise which was later questioned since in his Dichterinsul, Justi, as he himself admitted, was influenced by an allegory in

Nokkala - Nicholas B. Miller (edd.), Cameralism and the Enlightenment: Happiness, Governance and Reform in Transnational Perspective (forthcoming, Routledge 2020).

4 Horst Dreitzel, Justis Beitrag zur Politisierung der deutschen Aufklärung, in: Hans Erich Bödeker Ulrich Hermann (edd.), Aufklärung als Politisierung: Politisierung der Aufklärung, Hamburg 1987, pp. 158-177; Hans Erich Böde Ke R, Das Staatswissenschaftliche Fächersystem im 18. Jahrhundert, in: Rudolf Vierhaus (ed.), Wissenschaften im Zeitalter der Aufklärung, Göttingen 1985, pp. 143-162.

5 Uwe Wilhelm, Das Staats- und Gesellschaftsverständnis von J.H.G. von Justi: Ein Beitrag zur Entwicklung des Frübliberalismus in Deutschland, Der Staat 30,1991, pp. 415-441; Marcus Oвert, Die naturrechtliche "politische Metaphysik“ des Johann Heinrich Gottlob von Justi (1717-1771), Frankfurt am Main 1992.

6 Ulrich Adam, The Political Economy of J.H.G. Justi, Oxford 2006; Ere Nokkala, From Natural Law to Political Economy: Johann Heinrich Gottlob von Justi on State, Commerce and International Order, Berlin 2019.

7 Gunter Grimm (ed.), Satiren der Aufklärung, Stuttgart 1975; Justi's satires were collected in three volumes: Johann H. G. von Justi, Scherzhafte und Satyrische Schriften, Berlin 1760; Beatrice RöscH-Wanner, J.H.G. von Justi als Literat, Frankfurt 1993.

8 Johann H. G. von Justi, Die Dichterinsul nach ihren verschiedenen Landschaften und denen darinnen befindlichen Städten und Einwohnern sowohl, als nach dererselben Gottesdienst, Staats- und Kriegsverfassung unpartheyisch beschrieben: benebst einem Lob-und Heldengedichte, Leipzig 1745.

9 Göttingische Zeitungen von gelehrten Sachen (Göttingen, 1744), December, no. 27, pp. 837-838. 
Addison and Steele's famous and widely read Spectator (1711-1712). As Frensdorff has pointed out, a very similar allegory had just been published in the Spectator's German translation Zuschauer. The only difference was that Justi's essay grew to 128 pages. ${ }^{10}$

Justi made his academic name by winning an essay competition on monads organised by the Berlin Academy in $1747 .{ }^{11}$ That same year he was appointed to the service of the Duchess of Saxe-Eisenach, Anna Sophie Charlotte of Brandenburg-Schwedt (1706-1751). Not so well known is that Justi also anonymously published an essay in 1747 called Beweiß, daß die Universalmonarchie vor die Woblfahrt von Europa und überhaupt des menschlichen Geschlechts die grösste Glückseligkeit würken würde (1747), ${ }^{12}$ which turned out to be a success as well. The essay that is being analysed in this article has the appearance of being a defence of the idea of universal monarchy. It is difficult to say whether Justi's essay was written before or after he was appointed to serve the Duchess. However, it is easier to point to a link between the essay and Justi's next destination, Vienna, where he moved in 1750 and was later called upon to become a professor at the Theresianum. Most probably Justi's essay was greeted favourably in Vienna because one of its core messages was to call for a stronger Habsburg imperial government. After all, the essay was written in the aftermath of the death of Charles VII (1697-1745), when Francis I (1708-1765) was already the Emperor of the Holy Roman Empire. Justi directly reflected the contemporary situation of the Empire and wrote in the essay several times that he wished to see the Emperor's power on a stronger footing. ${ }^{13}$

$10 \quad$ F. FrensdorfF, Über das Leben, p. 367.

11 Johann H. G. von Justi, Nichtigkeit und Ungrund der Monaden, Halle 1748; Thomas Ahnert, Newtonianism in early Enlightenment Germany, c. 1720 to 1750: Metaphysics and the critique of dogmatic philosophy, Studies in History and Philosophy of Science 35, 2004, pp. 471-491; Avi Lifschitz, Language and Enlightenment: The Berlin Debates of the Eighteenth Century, Oxford 2012.

12 [Anon.], Beweiß, daß die Universalmonarchie vor die Woblfahrt von Europa und überhaupt des menschlichen Geschlechts die grösste Glückseligkeit würken würde, Frankfurt und Leipzig reprinted in Johann H. G. von Justi, Gesammlete politische und Finanzschriften, Koppenhagen 1761, vol. 2, pp. 235-300. Justi's essay is referred to in the following pages as J. H. G. von Justi, Berweiß.

13 J. H. G. von Justi, Beweiß, pp. 32-33. „Man mag mich vor einen Staats-Ketzer halten oder nicht: so kan ich mich doch der Gedanken nicht entschlagen, daß Teutschland glücklich, in der That recht sehr glücklich gewesen seyn würde, wenn dem Kayser Ferdinand dem andern gelungen wäre sie Kayserliche Gewalt auf einen höhern Fuß zu setzen." See also J. H. G. von Justı, Berweiß, pp. 35-36. „Ehemals konte doch der Kayser dergleichen zum Unglück ihrer Unterthanen gebohrne kleine Fürsten der Landes-Regierung entsetzen; und was war wohl gerechtiger, billiger und löblicher als diese Befugniß. Allein man hat ihn nunmehr auch diese Gewalt beschnitten und die kleinen Fürsten umdesto kühner gemacht, daß sie sich nunmehr bey dem tyrannischen Verfahren über ihre Unterthanen nicht die geringste Besorgung zu machen nöthig haben. Es wurde zuerst in die Wahlcapitulation Kayser Carl des VII gesetzt, [ - - - ]; und die Wahlkapitulation Kayser Franz I. ist derselben in allen Gleichförmig." See Wolfgang Burgdorf, Johann Heinrich Gottlob von Justi (1720-1771), in: Heinz Duchhardt [et. al.] (edd.), Europa-Historiker, Göttingen 2006, pp. $51-78$, see 63 . 
In the most recent literature touching on Justi's international political thought he has been mistakenly represented as someone who „recommends the establishment of a universal monarchy ${ }^{114}$ and as a champion of universal monarchy. ${ }^{15}$ This is the result of taking Justi's essay on universal monarchy at face value. Wolfgang Burgdorf argued in 2006 that Justi's defence of universal monarchy was a camouflaged contribution (ein getarnter Beitrag) to the discussion on the reform of the constitution of the Holy Roman Empire. ${ }^{16}$ As one of the foremost experts on the early modern Reich, Burgdorf was well-versed enough to recognise and interpret Justi's comments on the constitution of the Holy Roman Empire. ${ }^{17}$ Unfortunately Burgdorf's interpretation seems to have gone unnoticed, especially by Anglophone scholars. The reason may be that Burgdorf published his chapter in German, and therefore it has had a limited reception outside the German-speaking world. However, leading German scholars still maintain that Justi truly and seriously advocated the establishment of a universal monarchy. ${ }^{18}$ In this article, I am building on Burgdorf. Not unlike Burgdorf, I argue that Justi's essay on universal monarchy was in the first instance a commentary on the constitutional reality of the Holy Roman Empire and that its main aim was to support the strengthening of the power of the Emperor. My interpretation differs from Burgdorf's interpretation in two ways. First, I emphasise that Justi's essay is to be seen as a natural continuation of his activities as a satirist. In order to establish that Justi's essay was a satire, I seek to show that it was an ironic commentary on the genre of peace proposals and on texts on universal monarchies. To accomplish this, it is necessary to contextualise Justi's piece with other similar texts from the time of the War of the Austrian Succession. Second, I will relativize the distance that Justi took from his piece in 1761 when he republished it under his name in his collected political and financial writings. ${ }^{19}$ As Justi himself stated in the footnote, his arguments were still

14 David Armitage - Jennifer Pitts (edd.), H. Alexandrowicz, The Law of Nations in Global History. Oxford 2017, 173 footnote 13. For a short discussion of Justi's universal monarchy see Francis Cheneval, Philosophie in weltbürgerlicher Bedeutung: Über die Entstehung und die philosophischen Grundlagen des supranationalen und kosmopolitischen Denkens der Moderne, Basel 2002, pp. 313-315.

15 Martin Espenhorst, Frieden Erdenken: Vormoderne Perspektive auf Europa, Baden-Baden 2015, pp. 25-38.

16 W. Burgdorf, Johann Heinrich Gottlob von Justi, p. 61.

17 Wolfgang Burgdonf, Reichskonstitution und Nation. Verfassungsreformprojekte für das Heilige Römische Reich Deutscher Nation im politischen Schrifttum von 1648 bis 1806, Mainz 1998.

18 See for instance M. Espenhorst, Frieden Erdenken.

19 J. H. G. von Justi, Gesammlete politische und Finanzschriften, vol. 2, p. 235. „Unterdessen haben meine Beweißgründe an sich selbst ihre gute Richtigkeit." Burgdorf sees that Justi was distancing himself from his text of 1747 in 1761. . See W. Burgdorf, Johann Heinrich Gottlob von Justi, p. 63. 
valid. Here, I believe Justi is alluding to his views on wider European discussions on peace plans and political economy. ${ }^{20}$

Even in 1761 Justi held a view according to which larger monarchies should be prioritised. He believed that larger monarchies could bring about peace and prosperity. As a corollary, Justi's essay on universal monarchy continued to function as an attack on minor German princes, whom Justi considered petty tyrants. The good order of the state and a well-functioning economy were, according to Justi, a necessity for the survival of the state given the growing commercial rivalry between states. Consequently Justi's ideas on international order were oriented towards commerce and sea trade. His international political thought relating to his defence of universal monarchy can be placed in the context of the War of the Austrian Succession (1740-1748). ${ }^{21}$ In order to preserve freedom, the ,inner strength“ of the state was a necessity. Justi's international political thought is therefore an extension of his views on the forces underlying the existence of the state. His approach to international order was fundamentally commercial, as is also exemplified by his later pamphlets on the balance of power and the balance of trade. ${ }^{22}$

\section{The Changing Meanings of the Concept of Universal Monarchy}

It is important to keep in mind that Justi's essay on universal monarchy takes its place in a long tradition of treatises on the possibility of peace common in early modern European political thought. The idea of a single ruler governing the whole world was well-known from the Roman Empire, and it had its central place in Christian theology as well. Perhaps the most famous advocate of universal monarchy was Dante Alighieri (1265-1321), who argued that universal monarchy would liberate the world from chaos and guarantee peace. Dante was to a great extent building on the Aristotelian premises

20 Istvan Hont, Jealousy of Trade: International Competition and the Nation-State in Historical Perspective, Cambridge 2005; U. Adam, The Political.

21 On media and propaganda during the War of the Austrian Succession see Barbara Stollberg-RILinger, Maria Theresia: Die Kaiserin in ibrer Zeit: Eine Biographie, München 2017, pp. 445-459;

Silvia Mazura, Die preußische und österreichische Kriegspropaganda im Ersten und Zweiten Schlesischen Krieg, Berlin 1996; Sebastian Küster, Vier Monarchien - vier Öffentlichkeiten. Kommunikation um die Schlacht bei Dettingen, Münster 2004.

22 Johann H. G. von Justi, Die Chimäre des Gleichgewichts von Europa: Eine Abhandlung, worinnen die Richtigkeit und Ungerechtigkeit dieses zeitherigen Lehrgebäudes der Staatskunst deutlich vor Augen geleget, und dabey allenthalben neue und rübrende Betrachtungen über die Ursachen der Kriege und dem wesentlichen Grunde, worauf die Macht eines Staats ankommt, beygebracht werden, Altona 1758; Johann H. G. von Justi Die Chimäre des Gleichgewichts der Handlung und Schiffahrt, oder, Ungrund und Richtigkeit einiger neuerlich geäusserten Meynungen von denen Maassregeln der freyen Mächte gegen die zu befürchtende Herrschaft und Obermacht zur See: wobey zugleich Neue und wichtige Betrachtungen über die Handlung und Schiffahrt der Völker, und über den höchsten Punkt der daraus entstehenden Macht und Glückseligkeit beygebracht werden, Altona 1759. 
of the single end or purpose (telos) of humanity. In his concept, humankind formed a unity. ${ }^{23}$ The universality of being that Aristotle proclaimed in his Metaphysics was regarded as an argument for universal monarchy as a world order. ${ }^{24}$ Another famous defender of universal monarchy was Tommaso Campanella (1568-1639). In his Monarchia di Spagna (written in 1600-1601, published in Latin in 1640 as De Monarchia Hispanica), Campanella argued for the benefits of having a world ruled by Spain. ${ }^{25}$ On the Protestant side, it is more difficult to find defenders of universal monarchy. Protestant theorists often either connected universal monarchy with the Catholic Church and its institutions or with the imperial pursuits of Catholic princes, most famously those of Louis XIV. ${ }^{26}$

Especially among Protestant writers, the concept of universal monarchy had negative connotations, and it was intimately associated with Catholic pursuits of universal monarchy, such as the Pope's attempt to become more powerful. Several Protestant thinkers considered the concepts of universal monarchy, tyranny, popery and even Antichrist to be entangled. ${ }^{27}$ However, the confessional aspects of the negative uses of the concept of universal monarchy should not be overemphasised. Universal monarchy was used as a tool in the propaganda of Catholic states as well. For instance, France's aspirations to establish a universal monarchy were used as an argument on the Austrian side to justify the quadruple alliance between the Dutch Republic, the Holy Roman Empire, Spain and the exiled Duke of Lorraine in 1673 against France and Louis $\mathrm{XIV}$ in particular. In this alliance, Catholic and Protestant powers allied themselves against French aspirations to dominate Europe. In this context, the cameralist Johann Joachim Becher (1635-1682) anonymously published a pamphlet called Machiavellus Gallicus (1675). This pamphlet was in fact a satire that depicted the future of Europe

23 Dante Alighieri, Monarchy, Cambridge 1996, p. 19, 28, 82; Martti Koskenniemi, International Community from Dante to Vattel, in: Vincent Chetail - Peter Haggenmacher (edd.), Vattel's International law from a XXI Century Perspective, Leiden 2011, pp. 51-75, p. 54.

24 W. D. Ross (ed.), Aristoteles, Metaphysics, Oxford 1924, VI, 2, 1027a10; Martin van Gelderen, Universal Monarchy, The Rights of War and Peace and the Balance of Power: Europe's Quest for Civil Order, in: Bo Stråth - Hans-Åke Persson (edd.), Reflections on Europe: Defining a Political Order in Time and Space, Frankfurt am Main 2007, p. 50; See also Franz Bosbach, The European Debate on Universal Monarchy, in: David Armitage (ed.), Theories of Empire, 1450-1800, Aldershot 1998, pp. 81-98.

25 Tommaso Campanella, De Monarchia Hispanica. Discursus, [Amsterdam] 1640; Peter Schröder, Trust in Early Modern International Political Thought, 1598-1713, Cambridge 2017, pp. 46-47; John Robertson, Universal Monarchy and the Liberties of Europe: David Hume's Critique of an English Whig Doctrine, in: Nicholas Phillipson - Quentin Skinner (edd.), Political Discourse in Early Modern Britain, Cambridge, 1993, pp. 349-373, here p. 356; John Robertson, The Case for the Enlightenment: Scotland and Naples 1680-1760, Cambridge 2005, p. 156.

26 M. Koskenniemi, International Community from Dante to Vattel, p. 63.

27 M. van Gelderen, Universal Monarchy, pp. 57-58. 
if France were to dominate the future universal monarchy of Europe according to its own principles. In a satirical manner, Becher refers to the happiness of all nations under the French rule. As the title of Becher's pamphlet suggests, Machiavelli's soul was alive in Louis XIV. ${ }^{28}$ In short, Justi was not the first cameralist to write a satire on universal monarchy.

Despite these negative connotations, universal monarchy remained a key concept of international political thought in the early modern period. ${ }^{29}$ However, another concept gradually replaced it as the main interpretative framework of international relations. Balance of power started to be the most commonly used concept to analyse international order in the course of the eighteenth century. ${ }^{30}$ The power struggle and rivalry between the Bourbons and the Habsburgs, and the balance between these two powers, was central to this constellation. Hence universal monarchy remained as a powerful image because the disturber of balance started to be associated with the image of universal monarchy. In other words, balance of power and universal monarchy were counter-concepts. Charles Davenant (1654-1714) provides an example of how both concepts were simultaneously applied. He argued that only the maintenance of a multicentric world of small states sustained by a balance of power could prevent the rise of a universal monarch. A similar view was expressed by David Hume in the second half of the eighteenth century, and there are examples of the use of universal monarchy in this sense as late as 1770 . Hume used the notion of universal monarchy to argue the need to abandon any English isolationist foreign policy. The hegemonic pursuits of France could be balanced only by a coalition in which England was one of

28 Johann Joachim Becher, Machiavellus Gallicus: Das Ist: Verwandelung Und Versetzung Der Seele Des Machiavelli in Ludovicum XIV. Dem König von Frankreich, Vogestellet Durch Hundert Politische Frantzösische Axiomata, In Welchen Der Frantzosen Staats- Und Kriegs-Maximen Und Practicquen, Welcher Sie Sich Gebrauchen, Jedem Offentlich Zu Sehen Vorgestellet Werden, [s.1.] 1675. See point 1: „Die Französische Königliche Monarchie / ist zu dem End von Gott in die Welt gesetzt / damit sie / als eine Regiererin des Aller-Edelsten Volcks / die allgemeine Monarchie des gantzen Europa an sich bringe / und folgends das vollkommene Arbitrium über den ganzen Erdenkreis in Händen haben und führen solle“. See also point 4: „Warum? Es ist nur eine Sonn; also soll nur ein Welt-Monarch und dieses der Französische sein. Die sonn ruhet nimmer / also auch die Französische Regier-Sucht. Die Sonn ist feurig und hitzig / also auch der Französische Humor. Die Sonn ist Herrscherin des Gestirns; die Franzosen sollen es sein der Erden / (si Diis placet.) Die Sonn erwecket die Welt / das thut auch das Französische Geld. Die Sonn blendet die Augen: Französisches Geld und Wort das Gemüt. Am Feuer brennt man sich / also auch an den Franzosen. Die Sonnenstrahlen durchdringen das innersten der Erden / mit ihren Kräften: Die Französische Goldstrahlen durchdringen auch die geheimeste Rahts-Kammern der Könige und Fürsten / etc. Wenn wolte nun leugnen / daß der König in Frankreich / nicht das Sinnbild der Sonnen mit Recht führe“. I am grateful to Ivo Cerman for bringing this pamphlet to my attention.

29 Franz Bosвасн, Monarchia universalis: Ein politischer Leitbegriff der frühen Neuzeit, Göttingen 1988, preface, p. 9.

30

IвIDEM, pp. 9-17. 
the members. Only in this way was a French universal monarchy preventable. ${ }^{31}$ It is worth noting that the concept of universal monarchy was later revived for polemical use in propaganda against Napoleon. ${ }^{32}$

\section{Universal Monarchy in the Context of the War of the Austrian Succession}

It is necessary to take a more precise look at the use of the concept of universal monarchy in the context in which Justi was using it. In the context of the War of the Austrian Succession in which Justi's essay was published, universal monarchy was a negative concept most commonly applied to denounce French hegemonic foreign policy. Justi's position in his essay on universal monarchy is rather idiosyncratic, and it appears as an anomaly. As we will see, the concept of universal monarchy was used negatively in this context, with the sole exception of Justi's essay.

Johann Jacob Schmauss (1690-1757), ${ }^{33}$ the last in the great politico-legal tradition of Halle and pre-eminent among the natural lawyers and political scientists in Göttingen, shows how the relationship between universal monarchy and the balance of power between nations was understood in the context of the War of the Austrian Succession. Schmauss argued that the power of France was so great that it could be balanced only by the rest of Europe. According to Schmauss, the French would become the masters of all Europe if all other European forces did not unite their forces to balance it. ${ }^{34}$ As in the case of Hume, this was an appeal to England. England had to take a central role in counterbalancing France. Using ironic tones, an anonymous pamphleteer of Der Universal-Geist der Krone Frankreich, Als die Mißgeburth der Politic (1745) asserted that France's name could not be mentioned without the issue of universal monarchy arising. Commentators were immediately moved to discuss the French aspiration towards universal

31 J. Robertson, Universal Monarchy, pp. 368-369; M. van Gelderen, Universal Monarchy, p. 70.

32 Philip Dwyer, Napoleon and the Universal Monarchy, History 95, 2010, pp. 293-307.

33 Wolfgang SeLLerT, Johann Jacob Schmauss: Ein Göttinger Jurist, Juristische Schulung 11, 1985, pp. 843-847; Gottfried ZIEGLER, Die ersten hundert Jabre Völkerrecht an der Georg-August-Universität Göttingen: Vom Ius naturae et gentium zum positiven Volkerrecht, in: Fritz Loos (ed.), Rechtswissenschaft in Göttingen: Göttinger Juristen aus 250 Jahren, Göttingen, 1987, pp. 32-74.

34 Johann Jacob Schmauss, Einleitung zu der Staats-Wissenschafft, und Erleuterung des von im herausgegebenen Corposris Juris Gentum Academici und aller andern seit mehr als zweyen Seculis her gechlossenen Bündnisse, Friedens- und Commercien -Tractaten. Erster Theil, Die Historie der Balance von Europa, der Barriere der Niederlande, der Oesterreichischen Sanctionis pragmatigae, und anderer dahin gehörigen Sachen und Tractaten in sich haltend, Leipzig 1741, pp. 626-627. „Dannenhero eigentlich und der Wahrheit nach zu reden, schon vor der Zeit des Spanischen Successions Krieges die Balance von Europa nicht in einer Gleichheit zwischen Frankreich und Oesterreich, sondern in einer Gleichstellung zwischen Frankreich und dem Überrest von Europa bestanden hat. Dieses ist dann der gegenwärtige Zustand von Europa, in Ansehen seiner Balance gegen die überwiegende Macht von Frankreich.“ 
monarchy. ${ }^{35}$ This was no wonder since France seemed to be aiming to write laws for the whole of Europe. This was particularly worrisome for the Germans, to whom French universal monarchy appeared as a substantial threat. The pamphleteer moved on to the different uses of the concept of universal monarchy: in politics, universal monarchy was an element of state prudence (Staatsklugheiten); in ethics, it gave reasons to hate France; in peace treaties, it was a point made against expansionist politics; in war, it was the first sentence in the declaration of a conflict; and among those who wrote about the balance of power or wished to support it, it was the chef d'cuvre, often presented as the cause of the war. Elsewhere, it was simply a fat, moral animal, from whose milk greedy ministers sought their nourishment. ${ }^{36}$

The author of Das Entlarvte Franckreich (1745) argued that the French pursuit of general European monarchy constituted a real threat. After all, there were examples of universal monarchs in European history. It was less likely that a single monarch would rule the whole world. ${ }^{37}$ This pamphleteer further argued that the French power and its attempts to establish a universal monarchy had to be countered. The pro-Habsburg author pointed out that France had tried to eliminate its true counterweight, Austria. Balancing the power of France was a necessity for the happiness of Germany and the whole of Europe. ${ }^{38}$

The negative uses of the concept of universal monarchy became so common and were employed on so many levels - including the local and pan-European level - that almost any illegal expansion became intertwined with universal monarchy. Rulers who tried to strengthen their power within the Reich were accused of having „French intentions“ - this is to say, intentions of establishing a universal monarchy. In particular, Frederick II of Prussia was indirectly accused of trying to play master of Germany, if not of the whole world. The various uses of the concept went so far that even a nobleman's aspirations to pursue more power were regarded as aspirations towards a „small universal

35 [Anon.], Der Universal-Geist der Crone Frankreich, Als die Mißgeburth der Politic, [S.1.] 1745), p. 3. „Wenn nur die Rede von Frankreich ist; so berühret man zugleich die Begierde dieser Crone, eine solche Monarchie in Europa einzurichten."

36 [Anon.], Der Universal-Geist, p. 3. „Dermalen schreyet ganz Europa darüber, daß Frankreich aus seinen Angeln trette, und andern Geseze vorschreiben wolle. Wir Deutschen fürchten uns für dieser Universal=Monarchie, wie für einem Ungeheuer. Wir erzehlen es unsern Kindern. In der Politick ist sie ein Staats= und Haupt=Artickel; In der Moral ein Argument, Frankreich zu hassen; Bey Friedens=Schlüssen das Augenmerk, diese Crone in gemessene Schranken zu setzen; bey dem Krieg der erste Satz in den Manifesten und Kriegs=Declarationen; und bey denen, die von dem Gleichgewicht in Europa schreiben, oder solches befördern wollen, ist sie das Chef d'Oeuvre, öfters die Ursache der Kriege, und dann und wann das fette moralische Thier, an dessen Milch die geizigen Ministers ihre Nahrung suchen."

37 [Anon.], Das Entlarvte Franckreich, oder, Das entdeckte Project von der europäischen Universal-Monarchie: nebst einer zum Anhang beygefügten Ode auf die grossen Weltbezwinger, Haag 1745.

38 [Anon.], Das Entlarvte Franckreich, p. 29. 
monarchy". In other words, the nobleman was trying to subordinate his neighbours to his „universal monarchy“. ${ }^{39}$ As these examples illustrate, in the context of the War of the Austrian Succession, universal monarchy was intimately associated with oppression and the pursuit of power. Almost all political activities opposed in Europe, in the Reich or in one's own village were described as attempts towards the imposition of universal monarchy. The alleged aspirant was seen as an over-ambitious warmonger bent on territorial conquests..$^{40}$ At first sight, Justi's essay on universal monarchy posed a radical challenge to these conventional uses.

\section{Justi's „Arguments“ in Favour of Universal Monarchy}

In his essay on universal monarchy, Justi argued that introducing a single ruler for Europe would secure peace and happiness for the continent. Here he was walking in the footsteps of Dante and other apologists of universal monarchy. Justi even went as far as to suggest that a universal monarch of Europe would promote the general happiness of all mankind. Justi published his daring essay anonymously, and it attracted a lot of attention. He departed radically from the more conventional uses of universal monarchy, and there is no denying that his piece was original.

According to Justi, a universal monarch was to be defined as a single ruler, an Alleinherrscher $^{41}$, who governed all European empires and countries. All other rulers would

39 [Anon.], Der Universal-Geist, p. 4 ,So weit ist es jetzt gekommen, daß, wenn bey uns ein Prinz nur ein wenig weiter geht, als er gehen soll, ihm sogleich zur Last gerechnet wird, daß er Französische Absichten führe [- - - ein gewisser grosser Prinz, der einer von den 7. Haupt-Säulen ist, wie ihn die Guldene Bulle beschreibet, in unserem Vatterland ein Freund von dergleichen Project. Kann er schon nicht die Welt bezwingen: so will er doch in Deutschland den Herrn spielen.“ [ - - - ] „Und, wenn man die Sache beym Licht recht besiehet: so denkt der Edelmann in Deutschland selbst auf eine kleine Universal Monarchie unter seinen Benachbarten. Nach den verschiedenen Graden der Stände wächst auch dieses Französische Ungeheuer mit auf.“

J. Robertson, Universal Monarchy, p. 356.

J. H. G. von Justi, Beweiß, p. 13-14. „So oft ich also von dem Universal-Monarchen rede, so verstehe ich einen mächtigen Alleinherrscher, dessen Beherrschung alle übrigen Europäischen Reiche und Länder würklich unterworfen sind, und von welchen die Regenten, die Stadthalter von ihrem Oberhaupt, Gesetze und Befehle annehmen müssen. Es liegt hier also ein ganz andrer Begriff von dem Universal-Monarchen zum Grunde, als sich der Herr Professor Kahle in dem Gleichgewichte von Europa gemacht hat; und die Scheinfreyheit, welche die übrigen Regenten daselbst behalten, bleibet ihnen hier gar nicht übrig." Justi was here questioning the position of Ludwig Martin KaHle, De trutina Europae quae vulgo adpellatur Die Balance von Europa, Göttingen, 1744, which was also translated to French by Johann Heinrich Samuel Formey (1711-1797) under the title Ludwig Martin KaHLE, La balance de l'Europe considérée comme la règle de la paix et de la guerre, Berlin, 1744). Kahle (1712-1775) had been appointed a professor of philosophy in Göttingen in 1737. Later he went to Hanau Staatsakademie, then to Marburg, before he gave up an academic career and became a lawyer in Berlin. Kahle's best-known treatise is his scholarly disputation De trutina Europae (1744), published when he was still active in Göttingen. In it he argued that the balance of power secured the natural equality of states, which would encourage a durable peace in Europe. In 
take their orders from the universal monarch. The establishment of a universal monarchy could happen either by contracts or by conquests. ${ }^{42}$ Justi remarked in the beginning of this essay that his aim was not to discuss whether a universal monarchy was possible to establish. He only aimed to show all the advantages he associated with such a rule. In short, Justi admitted that his essay was a mere theoretical experiment. This is a critical point when interpreting Justi's intentions with his essay. What had given Justi the impetus for his considerations was his observation that there were far too many powerless rulers in Europe, not to speak of Germany, who could not secure the peace, security and happiness of their subjects. In fact Justi regarded the majority of European rulers as guilty of this sin. They were only good at three things: causing wars due to their bellicosity, pauperising their subjects through heavy taxation, and spending insane sums of money on luxuries. To Justi, Germany, with its weak economy and incapacity to defend itself, exemplified the consequences of having too many princes. ${ }^{43}$ Germany was ruled by petty tyrants who excelled in complicating commerce between different parts of the Empire and impoverishing their subjects. Daringly, Justi mentioned two such petty

concrete terms Kahle was claiming that Spanish intervention in England's affairs of trade was about to destroy the balance of Europe. England would no longer be able to save Europe from French universal monarchy. England would not be able totake care of its task of holding the balance of power. Kahle, who presented the balance of power as the rule of war and peace in Europe, emphasised that peace in Europe would prevail as long as the powers of Austria and France were balanced. According to Kahle - and many other contemporary thinkers - European nations were living in a state of nature in which the strong were trying to dominate the weaker. Therefore, all states were enemies of each other. Kahle argued that because a predominant power was a priori dangerous to its neighbours the power of the predominant power should be equalised by coalitions of weaker states. A nation that was gaining so much in strength that it could extinguish its neighbours could legitimately be „balanced“. Kahle even justified preventive strikes in order to balance power between nations. He compared the balance of power system to the actions of a wise doctor, efficacious in simply cutting out everything harmful to the body. Additionally, in the name of the common interest, states could draw up contracts to the effect that some of them should relinquish territories; just as the individual „could be forced to sacrifice some of his personal wealth for the good of the community of which he was a member, so a ruler might justifiably be asked to give up territory to which he had every legal right, for the good of the European state system as a whole." Translation after ADAm, The Political, p. 74

42 J. H. G. von Justi, Berweiß, p. 13. „Man wird vielleicht aus dem vorhergehenden schon wahrnehmen, daß ich die Universal-Monarchie hier in dem eigentlichen Verstande nehme, und daß ich diejenige Gestalt von Europa darunter verstehe, nach welcher ein einziges grosses Reich alle übrige Staaten und Länder, es sey nun mit Gewalt der Waffen, oder durch Verträge, unter seine Oberherrschaft gebracht hat."

43 IвіDEм, pp. 31-32. „Teutschland giebt von dem allen, was ich gesagt habe, ein überzeugendes Beyspiel ab. Man gebe nur auf diejenigen Gründe Achtung, worauf ich die Schändlichkeit der Regenten gesetzet habe, so wird man die Unglücklichen Spuhren davon fast allenthalben gewahr werden. Wodurch wird wohl Teutschland, dieses mächtige Reich, ausser Stand gesetzt seinen Feinden die Spitze zu biethen, ja wodurch wird es dahingebracht, daß auswärtige Mächte mit demselben Spielen, wie sie wollen?“. 
tyrants by name: Wilhelm Hyacint von Nassausiegen (1666-1743) and Count Carl Leopold von Mecklenburg (1678-1747). ${ }^{44}$ These two tyrants had ruined the economies of their principalities by poor governing.

Not without irony, Justi argued that the establishment of a universal monarchy would put a stop to the wars between European states. No one would dare to take up arms against such a powerful ruler. The universal monarch would not have a bellicose nature because he would not have any need to expand a territory that was already so large. Another benefit would be a lower level of taxation across Europe. It would be impossible for the universal monarch to spend all his tax revenues on luxuries, no matter how wasteful he might be. ${ }^{45}$ In sum, the universal monarch would be powerful enough to provide happiness for his subjects. Because the universal monarch would have power over all European rulers, he would be able to put a stop to ancient hatreds among European nations, and, slowly, Europe would become a single nation (ein einziges Volk). Interestingly, Justi noted specifically that this would remove any basis for hatred between Swedes and Danes and between Frenchmen and Englishmen. ${ }^{46}$

As the greatest benefits of universal monarchy, Justi purported its economic advantages. This reflected his preference for larger commercial units. He opposed the idea of limiting trade within the borders of a small state. ${ }^{47}$ The lack of an external threat would allow the universal monarch to concentrate entirely on improving the domestic economy. Arms races between nations would be forgotten, since the universal monarchy would need only one army. Thus huge expenses and public debt could be avoided, since petty rulers would no longer need to maintain large armies. ${ }^{48}$ This would solve the issue of increasing indebtedness that had become so common in Europe. An even greater benefit would be the possibility of exchange across former borders. Justi noted that too many

44 IвIDEм, p. 34 „Was vor Beyspiele von kleinen Fürsten haben wir nicht in Deutschland, die entweder würkliche Tyrannen vorgestelet oder doch ihre Lande bis aufs Bluth ausgesogen haben. Ich darf kein Bedenken tragen den Herzog Carl Leopold von Mecklenburg und den Fürsten Wilhelm Hyacint von Nassau-Siegen öffentlich zu nennen." See also J. M. von Loen, Von der Universal-Monarchie, p. 252.

45 J. H. G. von Justi, Berveiß, pp. 79-80.

46 Iвidem, p. 70. „Durch Vielheit der Regenten und durch die zwischen einigen Völkern geführten langwierigen Kriege geschicht es, daß öfters Nationen einen angebohrnen tödlichen Haß gegen einander schöpfen. Die natürliche Feindschaft, die ehemals zwischen den Spaniern und Franzosen herrschte und die ietzo wieder aufzuleben scheinet, der angebohrne Haß der Franzosen und Engelländer, der Dännenmärker und Schweden sind hiervon unstreitige Zeugnisse.“

47 IвIDEm, pp. 21-22. „Dann der Handel und der Umgang läst sich nicht allein in die Gränzen eines jeden zu mahl kleinen Landes einschliessen.“

48 Iвidem, pp. 27-28. On the problem of public debt in eighteenth-century European political thought see Michael Sonenscher, Before the Deluge: Public Debt, Inequality and the Intellectual Origins of the French Revolution, Princeton 2007. 
rulers obstructed trade in general since conflicts between these figures harmed trade, and even neutral nations had to suffer from this injustice. He emphasised that the movement of wealth (Vermögen) would not be limited in a universal monarchy, and expressed hopes that ultimately all subjects would align themselves with the religious preferences of the monarch. And since God was gracious, divine providence would ensure that the right preferences would be chosen. ${ }^{49}$

Justi's unconventional use of the concept of universal monarchy went far beyond the contemporary uses of this concept. There were some earlier cases in which universal monarchy was used as a positive concept to legitimise European colonial conquests. ${ }^{50}$ In a different vein, Justi argued that mankind would benefit from a European universal monarchy because it would free Africans and Americans from the yoke that Europeans had imposed on them. Under a universal monarchy, Americans would no longer be forced to move continuously from one domineering European nation to another. Moreover, he argued, the people living in the East Indies would not be forced to sell their goods to one European nation only. Neither would they be forced to accept the prices set by Western merchants. Instead, they would be free to trade with those European nations that proved most pleasant and appealing to them. ${ }^{51}$ In addition, Turkey, Persia and the Tatars would no longer be continuously drawn into European wars that ran counter to their own interests. The universal monarch of Europe (der mächtige Universalmonarche) would be so powerful that he could influence the maintenance of peace between the „Muhammadan“ (mahometanischen) and other „barbaric nations“ (andern barbarischen Volkern). On the orders of the universal monarch, the latter would simply cease their hostilities, not unlike the European nations among themselves. ${ }^{52}$

49 J. H. G. von Justi, Beweiß, p. 74. „Es ist wahr, der Universal-Monarche könte eine falsche Religion haben. Allein man muß von der erbarmenden Gütigkeit GOttes und von seiner weisen Vorsehung hoffen, daß er es bey Einführung der Universal-Monarhie in die Wege richten würde, daß die wahre allgemein würde."

50 Anthony PAgden, Lords of All the World: Ideologies of Empire in Spain, Britain and France c. 1500-1800 (New Haven, 1995), p. 46. For discussion of the legitimacy of conquest see chapter 2, pp. 29-62.

51 J. H. G. von Justi, Beweiß, pp. 74-75. „Die Einwohner der Ostindianischen Insuln würden nicht genöthiget werden ihre Waaren nur vor ein einziges Volk einzusammlen und sich die nach der Kaufleuthe eigner Willkühr gesetzten Preise gefallen zu lassen: sondern sie würden die Freyheit haben; mit dienenjenigen europäischen nationen zu handeln, die sich am liebreichsten und gefälligsten gegen sich bezeugten."

52 Iвideм, p. 75. „Türken, Persianer und Tartern würden nicht von diesem oder jenem Europäischen Volk wieder andere christliche Mächte öfters zu ihrem eignen höchsten Schaden zum Kriege angereizet und aufgewiegelt werden, und was könte nicht der so mächtige Universal-Monarche beytragen auch den Frieden unter den Mahometanischen und andern barbarischen Völkern in andern Welttheilen zu erhalten?“ 


\section{Revisiting Justi's Essay on Universal Monarchy: An Interpretation}

One could talk of satirical use of paradiastole in the case of Justi's essay on universal monarchy. ${ }^{53}$ Paradiastole is a rhetorical trope which is used as a medium for changing the normative meaning of a concept. In his usage of the concept of universal monarchy, Justi gave a favourable turn to something not otherwise considered favourably by substituting one thing for another within the range of reference of the same concept. Justi was using paradiastole in an ironic way. He was praising something that in reality did not deserve to be admired. The most eminent commentator on the essay, Johann Michael von Loen (1694-1776), a rich merchant, a political theorist and Goethe's great-uncle, recognised the ironic character of Justi's essay. Loen praised the anonymous author for his beautiful and lively style. He observed that the pamphlet was admired both for its audacious proposal of a special doctrine of Staatsklugheit, and for its brave move in aiming an arrow at the free German princes. ${ }^{54}$

Justi's essay on universal monarchy is one example among many European texts on the possibility of perpetual peace in Europe. The most prominent was Charles Irénée Castel de Saint-Pierre's (1658-1743) Projet pour rendre la paix perpetuelle en Europe (1713). ${ }^{55}$ In Saint-Pierre's view, monarchy was not a suitable form of government for larger territories due to its instability. In his view, the confederacy of a „European Union" was a preferable solution for Europe. In his proposal for a confederacy, Saint-Pierre mixed sovereignty with a federal system, arguing that this combination could function in Europe as it did in the German territories. ${ }^{56}$ Saint-Pierre's proposal had a strong commercial element. His plan for a European Union would make commerce universal, free, equal, certain and perpetual amongst all European nations. This would give incentives for economic growth and global commerce. ${ }^{57}$ Saint-Pierre's ideas were revisited in the context of the War of the Austrian Succession. In a new proposal titled Projet d'un

53 Quentin Skinner rehabilitated the trope of paradiastole in his Reason and Rhetoric in the Philosophy of Hobbes, Cambridge 1996. See Q. Skinner, Reason, chapter 4. See also Kari PaLonen, Parliamentary Thinking, Procedure, Rhetoric and Time, Cham 2018, p. 99.

54 Johann Michael von Loen, Von der Universal-Monarchie, in: Freye Gedanken zu Verbesserung der Menschlichen Gesellschaft, Frankfurt am Main 1752, pp. 248-295, see page 248: „Folgende kleine Schrift macht aller Orten ein grosses Aufsehen." See also F. Cheneval, Philosophie in weltbürgerlicher Bedeutung, pp. 313-315.

55 Charles Irénée Castel de SAInT-Pierre, Projet pour rendre la paix perpetuelle en Europe, Utrecht 1713; Olaf Asвасн, Staat und Politik zwischen Absolutismus und Aufklärung: der Abbé de Saint-Pierre und die Herausbildung der französischen Aufklärung bis zur Mitte des 18. Jahrhunderts, Hildesheim 2005.

56 Peter Schröder, The Holy Roman Empire as model for Saint-Pierre's Projet pour rendre la Paix perpétuelle en Europe, in: Robert John Weston Evans - Peter H. Wilson, The Holy Roman Empire, 1495-1806: A European Perspective, Leiden 2012, pp. 35-50.

57 I. Hont, Jealousy of Trade, pp. 26-27. 
nouveau système de l'Europe, préférable au système de l'Equilibre entre la maison de France et celle d'Autriche (1745), ${ }^{58}$ an anonymous pamphleteer argued that a European republic modelled on the union of Germany, Holland and Switzerland would guarantee peace in Europe more reliably than a situation depending on the balance of power between Austria and France. Peace in Europe could be secured by establishing a European Republic. The pamphleteer idealised in particular the constitution of the Holy Roman Empire, and used it as an example of how to organise a federal republic of Europe. ${ }^{59}$

Justi commented on the idea of a European republic and the aforementioned pamphlet in his Untersuchung: Ob Europa in eine Staatsverfassung gesetzet werden könne, wobey ein immerwährender Friede zu hoffen ist? (1746), which predates his essay on universal monarchy. In this essay, Justi denies the possibility that establishing a „European constitution" would secure peace in Europe ${ }^{60}$ He held the idea of such a European constitution as a basis for a federal European republic as unrealistic. In the nations that were used as models for unification such as Greece, Switzerland and Holland, there had always been a common interest. The fear of Persia had served to unite the Greeks. The threat of Spain had moved the Netherlands to unite, whereas in Switzerland it was the fear of tyranny practiced by the bailiffs (Landvögte) that promoted unification. Justi considered Germany as a special case, and he rejected the application of it as a model for a European Republic on several grounds. To begin with, the various parts of Germanywere not fully free, and they had only slowly grown together. Justi did not recognise any common interest among European nations that would support the unification of European nations. There was not even a common enemy. In addition, Justi asserted that even if such unification were possible, it would hardly secure peace in Europe. He took the examples of Greece, the Netherlands and Switzerland, where peace had not prevailed among the member states either. According to Justi, this had to do with the fact that unification did not remove the passionate nature of human beings: subjects would remain tempted to pursue greater power, which would cause conflicts. An even more difficult obstacle to establishing a European federal republic was related to decision-making. Justi asserted that decisions could be either unanimous or made by a majority. Since the interests of the European nations varied so greatly, it would be unlikely that unanimous decisions were realistic. If the decisions were made on the basis of a majority, binding the minority to adhere to the decision would be problematic. Those nations that were

58 [Anon.], Projet d'un nouveau système de l'Europe, préférable au système de l'Equilibre entre la maison de France et celle d'Autriche, [s.1.] 1745.

59 [Anon.], Projet d'un nouveau système, p. $19 \mathrm{ff}$.

60 Johann H. G. von Justi, Untersuchung: Ob Europa in eine Staatsverfassung gesetzet werden könne, wobey ein immerwährender Friede zu hoffen ist?, in: Ergetzungen der vernünftigen Seele aus der Sittenlehre und der Gelehrsamkeit überhaupt, 2 (1746), pp. 39-56. Reprinted in Johann H. G. von Justi, Historische und Juristische Schriften, vol. I, Frankfurt 1760, pp. 171-184. 
left in the minority would be tempted to appeal to countries outside Europe to achieve their interests. For these reasons Justi regarded the unification of Europe under a federal structure as a potential source of war rather than as something that would guarantee peace in Europe ${ }^{61}$ In sum, he argued that federal structures would not serve to unify Europe. The only way Europe could be united, even if only in theory, was in the form of a universal monarchy.

In his essay on universal monarchy Justi used universal monarchy as a model for the constitution of the Holy Roman Empire. In a way, he did the opposite of what SaintPierre and the author of Projet d'un nouveau systeme did. Whereas the latter used the German constitution as an idealised model for the unification of Europe, Justi took the idea of universal monarchy in an idealised form and applied it to the constitutional reality of the Holy Roman Empire. When Justi republished his essay on universal monarchy under his own name in his Gesammlete Politische- und Finanz-Schriften (1761), he argued that when the essay was published for the first time, he wanted to discuss other matters than the benefits of universal monarchy. In the 1761 version, Justi stated that it was obvious for readers that universal monarchy would tend towards despotism, and readers such as von Loen recognised that Justi's text was not to be taken as a serious defence of universal monarchy. ${ }^{62}$ What makes Justi's later statement more reliable is the fact that, only a year before the first publication of his essay, he wrote that universal monarchy would be possible only in the form of a tacit universal monarchy. Rulers had fought against the creation of a universal monarchy for centuries. It was unlikely that they would be willing to accept it in the future, and in the essay itself Justi wrote that he was not even interested in whether universal monarchy was realisable or not. ${ }^{63} \mathrm{My}$ interpretation of Justi's essay as satire gains further support from the comments of Justi's contemporaries. ${ }^{64}$ For instance, von Loen read Justi's essay not as a defence of universal

61 J. H. G. von Justi, Untersuchung: Ob Europa, p. 177, pp. 180-181.

62 This was how Justi's first commentator Loen interpreted the essay. Loen's main argument against Justi's essay was that universal monarchy could not be established without enormous bloodshed, and that therefore it was a somewhat weak solution if the establishment of such a monarchy was to create peace in Europe. See J. M. von Loen, Von der Universal-Monarchie, p. 294. Justi praised Loen's interpretation in the editorial comments of the second edition. See Justi, Gesammlete, pp. 235-237.

63 J. H. G. von Justi, Beweiß, p. 14. This was already Justi's opinion in his Erörterung der Frage: $\mathrm{Ob}$ freye Mächte über die Länder eines Dritten nach dem Natur-und Volkerrecht Verträge zu machen befugt sind which dates back to 1746.

64 Die Neue Europäische Fama, welche den gegenwärtigen Zustand der vornehmsten Höfe entdecket, Leipzig 1747, 140 Theil, Erster Anhang, pp. 711-721; Zuverlässige Nachrichten von den gegenwärtigen Zustande, Veränderung und Wachstum der Wissenschaften, neunzigster Theil, Leipzig 1747, pp. 449-466, p. 466. „Solte im übrigen der Herr Verfasser diesen letzten Zweifel mehr zum Scherz als im Ernste beygebracht haben, wiewohl er sich sehr ernst dabey anstellet; so dürfte er uns wohl gar auf die Gedanken bringen, daß er seinen Beweis in ganz andern Absichten, als er angiebt, bekannt gemacht. 
monarchy but as an attempt to reveal other truths, ${ }^{65}$ such as views criticising the dismemberment of the Holy Roman Empire.

Further proof of Justi's familiarity with the use of irony in political essays is his interpretation of Machiavelli's The Prince. Justi argues that Machiavelli could not have meant his work seriously; rather, it was a satire that unmasked the real face of monarchical rulers. Justi regarded Machiavelli as a true republican and considered The Prince as a satire written against bad rulers. ${ }^{66}$ In my view Justi's essay had the same aim. It unmasked the real face of petty tyrants in Germany. It is worth noting that the editor of Justi's Natur und Wesen der Staaten, Heinrich Gottfried Scheidemantel (1739-1788), regarded Justi as a man who was more learned than cautious and therefore belonging to the same group as Machiavelli. ${ }^{67}$

\section{Conclusion}

Justi cannot be considered as someone who championed universal monarchy or seriously recommended the establishment of a universal monarchy in Europe. He was not even interested in discussing whether the establishment of universal monarchy was possible. His writing was more of an ironic commentary on the genre of peace proposals and presented his unconventional view in order to gain more readers. Still, there are good reasons why Justi did not include his essay on universal monarchy in his collection of satires, despite its satirical elements; rather, it was published together with his collected political and financial writings. This can be assumed to have been because the piece contained several arguments that recur in his later writings. In it Justi attacked the bellicosity of petty rulers in an unambiguous way. ${ }^{68} \mathrm{He}$ maintained that wars were a result of the petty interests of luxurious tyrants who were only good at pauperising their subjects by high levels of taxation which destroyed the economy. Furthermore, he mentions the sanctity of private property, a certain level of civil liberty and the prohibition of offensive

Wenn er neml. den Nachtheil, der aus der Vielheit der Regenten entstehet, erweisen will so nimmt er daher Gelegenheit, verschiedene Fehler der Regenten, und sonderlich der kleineren in Deutschland, etwas lebhafft zu beschreiben, und das Unglück welches dem Vaterlande heraus erwächset, vor Augen zu stellen. Wofern sein Hauptabsehen gewesen, die Empfindlichkeit darüber an den Tag zu legen, so möchte er vielleicht seine ungegründete Glückseligkeit der Universal-Monarchie nur zur Gelegenheit gemacht haben, dieses geschickt anzubringen, und sich durch den Vortrag einer ungewöhnlichen Meinung Leser zu verschaffen.“

J. M. von Loen, Von der Universal-Monarchie, p. 249.

Johann H. G. von Justi, Der Grundriss einer guten Regierung, Frankfurt 1759, pp. 36-38. It is of course a matter of debate whether The Prince was a satire.

67 J. H. G. von Justi, Natur und Wesen der Staaten, Mitau 1771 [1760], Vorerinnerung des Herausgebers, p. xx.

68 On bellicosity see Jörn Leonhard, Bellizismus und Nation: Kriegsdeutung und Nationsbestimmung in Europa und den Vereinigten Staaten 1750-1914, München 2008. 
wars in the pamphlet, which are all themes that recur in his later works. In addition to these arguments, Justi's essay had a more topical point. In it, he appeals for stronger powers for the Emperor. However, the pamphlet was more than this appeal alone, because Justi's early essay on universal monarchy demonstrates that he began reflecting on wider questions of political economy, in the true eighteenth-century sense of the word, and the benefits of larger commercial monarchies before he was appointed as a teacher of cameral sciences at the newly-established Theresianum in Vienna. ${ }^{69}$ Justi's preference for larger commercial units, which was characteristic of his later work on political economy, was already present in draft form in this early essay, but it was by no means a defence of universal monarchy.

69 On noble education at Theresianum see Ivo Cerman, Habsburgischer Adel und Aufklärung: Bildungsverhalten des Wiener Hofadels im 18. Jahrbundert, Stuttgart 2010, p. 229. 


\section{Ere Nokkala}

\section{Justi’ s Essay on Universal Monarchy (1747): A Misunderstood Satire (Abstract)}

This article analyses Johann Heinrich Gottlob von Justi's (1717-1771) early essay on Universal Monarchy (1747) in the context of the broader eighteenth-century discussion of political order and commerce. During the eighteenth century, theorists often envisaged a universal society of all nations, or a universal monarchy under the rule of a single monarch. Alternatively, many others argued that peace and tranquillity among states could be secured through the orchestration of a balance of power between states. Justi's position in this debate is rendered somewhat puzzling because of his early essay on universal monarchy. Here, Justi argues that a monarch ruling the whole of Europe could secure peace and tranquillity in Europe. This would seem to make him one of the last serious defenders of a universal monarchy, as several previous scholars have asserted. This article argues, however, that Justi's essay on universal monarchy was a satire in which he commented on the Holy Roman Empire. He ridiculed petty tyrants and advocated strengthening the power of the Holy Roman Emperor. Justi's preference for larger commercial units, which was characteristic of his later work on political economy, was already present in draft form in this early essay.

KEY WORDS:

Johann Heinrich Gottlob von Justi; eighteenth century; cameralism; universal monarchy; satire 